Journal of Engineering and Applied Sciences 14 (7): 2258-2261, 2019

ISSN: 1816-949X

(C) Medwell Journals, 2019

\title{
Crack Formation Study in a Dam of a Formed Technogenic Deposit
}

\author{
Kaerbek Rafkatovich Argimbaev, Dmitry Nikolaevich Ligotsky, \\ Loginov Egor Vyacheslavovich and Kristina Vladimirovna Mironova \\ Saint-Petersburg Mining University, 21 Line V.O., 2, \\ 199106 Saint Petersburg, Russian Federation
}

\begin{abstract}
Dam construction during a technogenic deposit formation in harsh climatic conditions is complicated by cooling and subsequent freezing of tails deposited in dams. Due to this reason, frost cracks may form in the crest and in the dam deposition beach. These cracks are hazardous by a number of reasons. By splitting the dam body into separate segments they decrease its reliability and slope stability. Cracks decrease the water filtration path from a settling pond, thus, increasing head gradients and facilitating tail carry-over from the dam body. Cracks unfavorably affect operating conditions of pressure piping and may cause their failure. The study contains the field survey results that will provide insight into the crack opening width and depth.
\end{abstract}

Key words: Technogenic deposit, dam, crack, survey stakes, crack opening width, crack depth

\section{INTRODUCTION}

Accidents at mining facilities including tailing dumps (technogenic deposits) take place almost every year in different countries, whereby their consequences provide an evidence of a serious hazard for humans, engineering structures and environmental components.

In this regard, construction and operation of raised tailing ponds in a safe mode with the least accident risk become increasingly important and require the fastest solution to develop and implement measures that will reduce the risk and increase the technogenic deposit stability which is associated with process features of the dam raise and construction (Argimbaev et al., 2016; Pikalov et al., 2016; Danilov et al., 2015; Pashkevich and Petrova, 2015).

To start assessing these adverse effects, it is necessary, first of all, to know, how cracks are located on the dam surface and what are their dimensions (crack's opening width and depth, the inter-crack distance). Gavrishev et al. (2016), Argimbaev et al. (2018), Pikalov et al. (2016), Balaji et al. (2013). Unfortunately, papers contain minor data concerning this issue. That's why the field observation data are of great interest which were collected at the dam of a tailing dump located in harsh climatic conditions (in Winter, air temperature decreases to minus $55^{\circ} \mathrm{C}$ and wind speed may reach 40 $\mathrm{m} / \mathrm{sec}$. The dam was raised from the tailings accumulated at the dump (average diameter $d_{c p}$ is $0.24 \mathrm{~mm}$ ), it is $4.7 \mathrm{~km}$ long and $50 \mathrm{~m}$ high. Dam width by the crest is $10-15 \mathrm{~m}$.
The deposition beach length is $70-80 \mathrm{~m}$, its slope is $1: 20$. Average rate of downstream slope is $1: 4$ (Kholodnyakov and Argimbayev, 2014; Kaerbek and Kholodjakov, 2016; June and Khalaf, 2009; Sarma, 1979). Examination of the crest and deposition beach has shown that cracks were formed mainly in the Southern part of the dam. Probably, it may be explained by the prevailing wind direction in the Winter period.

\section{MATERIALS AND METHODS}

Crack's directions in relation to the dam crest were defined visually, according to available possibilities. A metal tape was used to measure crack's length, opening width and the inter-crack distance. Crack's depth was measured using a steel test rod $1.5 \mathrm{~mm}$ in diameter (this procedure resulted in certain underestimating of the crack's depth).

As a result of the study, crack's location map was drawn and crack's parameters were obtained. Figure 1 and 2 illustrate specific crack's location maps as an example. Table 1 contains the measuring results for crack's parameters.

The possibility to estimate the crack formation parameters is important for design engineering. The tailing dump dams are compound shape bodies, however, due to the dimensions of the surface layer exposed by negative temperature, solutions for a plane and linear problems may be used to determine the crack's formation parameters. We used the method proposed by Prof. G. Kholodnyakov

Corresponding Author: Kaerbek Rafkatovich Argimbaev, Saint-Petersburg Mining University, 21 Line V.O., 2, 199106 Saint Petersburg, Russian Federation 


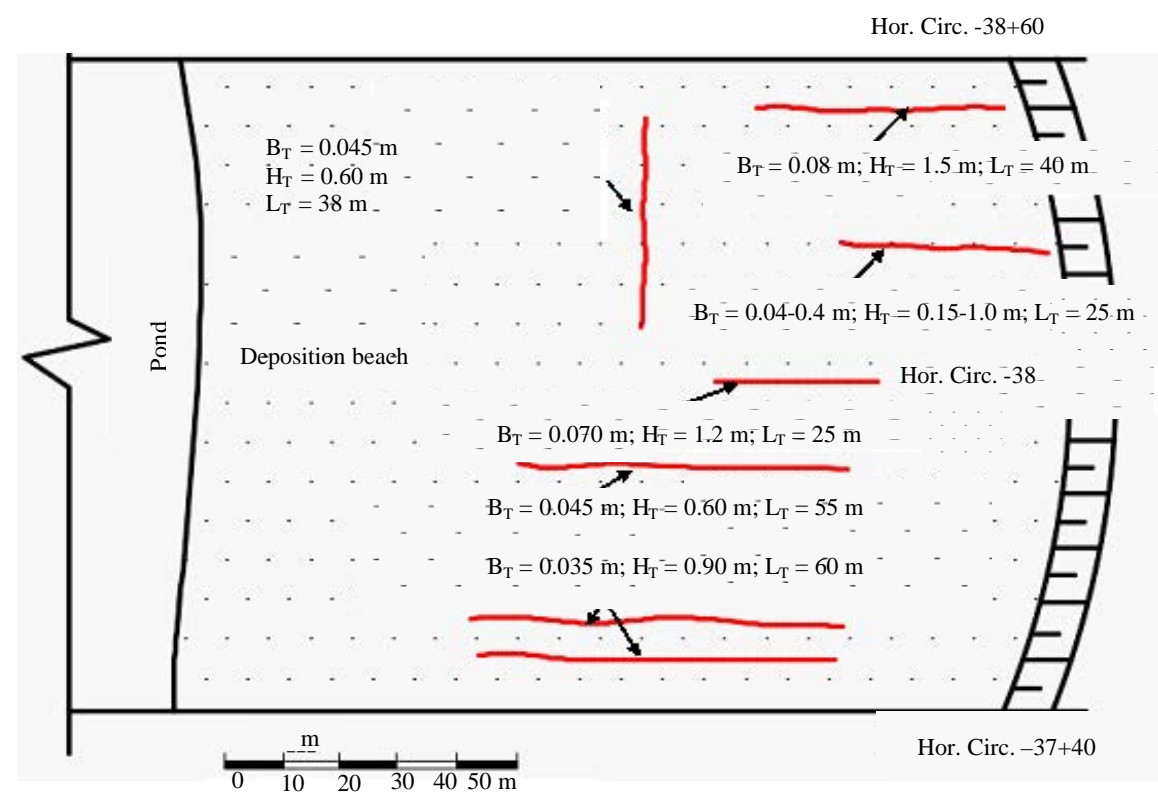

Fig. 1: Frost crack's location at the section between stakes (horizontal circle) $-37+40$ and $-38+60$ of the tailing dump dam BT-crack width, m; HT crack depth, m; LT crack length, m

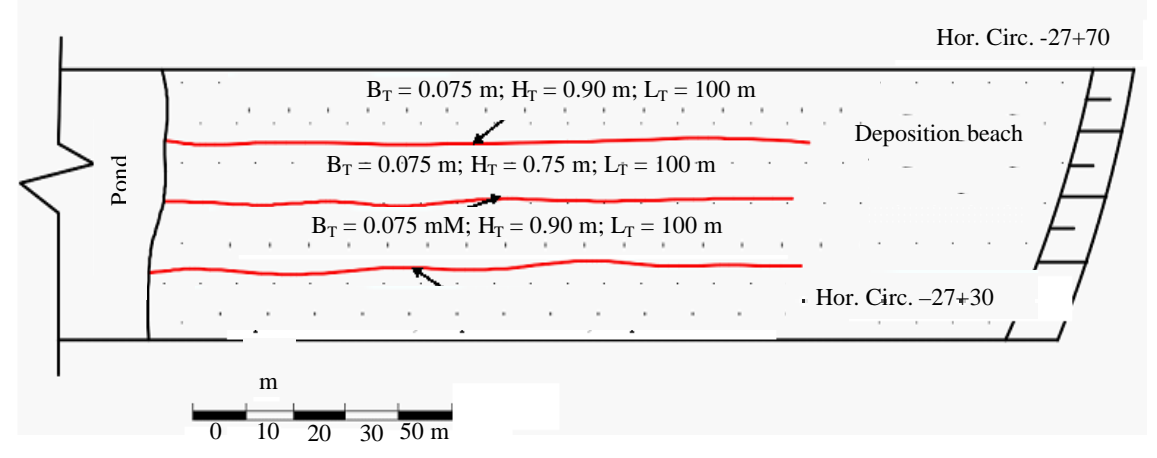

Fig. 2: Frost crack location at the section between stakes (horizontal circle) $-27+70 \mathbf{n}-27+30$ of the tailing dump dam T-crack width, m; HT crack depth, m; LT crack length, m

$\underline{\text { Table 1: Measuring results for crack parameters }}$

\begin{tabular}{llcc}
\hline & \multicolumn{2}{c}{ Crack's parameters (m) } & \\
Zone & Depth & Opening width & Inter-crack distance \\
\hline Pre-pond & $0.55-1.5$ & $0.03-0.09$ & $1.5-7$ \\
Lateral & $0.8-1.2$ & $0.025-0.105$ & $1.5-7$ \\
\hline
\end{tabular}

to calculate crack's parameters (June and Khalaf, 2009). This choice was stipulated by a number of circumstances. G. Kholodnyakov's method is free of shortages inherent to a number of other methods (Sarma, 1979). The application of this method is facilitated by its being the basis for a numerical model and a computer program. The calculation algorithm is programmed in C\#. Cracking calculations were made for the above described tailing dump dam where the field survey was carried out.
Table 2 contains initial data for the calculation. Dynamics of the snow cover accumulation on the dam crest and deposition beach is given in Table 3 as well as the change of thermal characteristics depending on the snow layer height. The crack formation possibility was calculated for the pre-pond and lateral zones of the tailing dam. Two dam types were considered (thawed and frozen); case study was carried out per each dam type for the cases of snow cover availability/absence. Table 4 contains computation results. It follows from the above data that the cracking start time depends on the dam type and the snow cover presence/absence. Cracks in a frozen-type dam begin to form earlier than in a similar thawed-type dam. 
Table 2: Initial physical-mechanical properties of the dressing plant tailing

\begin{tabular}{lcc}
\hline & Values for the material & Of the lateral zone \\
Parameters (Unit) & Of the re-pond zone & 0,443 \\
\hline Tailing volumetric moisture (Unit fraction) & 0,525 & 2,04 \\
Tailing density $\left(\mathrm{t} / \mathrm{m}^{3}\right)$ & 1,95 & 148,0 \\
Volumetric heat of the tailing phase transitions $\left(\mathrm{MJ} / \mathrm{m}^{3}\right)$ & 176,0 & 1,$67 ; 1,33$ \\
Tailing heat conductivity $(\mathrm{W} / \mathrm{m} . \mathrm{K})$ & 1,$8 ; 1,4$ & 1,$72 ; 2,4$ \\
Tailing volumetric heat capacity $\left(\mathrm{MJ} /\left(\mathrm{m}^{3} . \mathrm{K}\right)\right.$ & 1,$8 ; 2,56$ & 1,4 \\
Heat distortion hangover time $\left(10^{-5} \mathrm{sec}\right)$ & 1,4 & 0,72 \\
Stress relaxation time $\left(10^{-5} \mathrm{sec}\right)$ & 0,72 & 180 \\
Instantaneous tensile strain modulus $(\mathrm{MPa})$ & 200 & 50 \\
Long-term tensile strain modulus $(\mathrm{MPa})$ & 65 & 10,0 \\
Linear expansion coefficient $\left(\mathrm{mK}{ }^{-1}\right)$ & 19,0 & 0,35 \\
Poisson ratio (Unit fraction) & 0,35 & 0,11 \\
Longitudinal tensile strength $(\mathrm{MPa})$ & 0,183 &
\end{tabular}

Table 3: Change of the snow cover thermal characteristics vs. its height

\begin{tabular}{|c|c|c|c|c|c|c|c|c|c|}
\hline \multirow[b]{2}{*}{ Parameters } & \multicolumn{9}{|c|}{ Time (days) } \\
\hline & 0 & 30 & 60 & 90 & 120 & 150 & 180 & 210 & 240 \\
\hline Snow lay er height $(\mathrm{H}, \mathrm{m})$ & 0 & 0,11 & 0,17 & 0,26 & 0,28 & 0,30 & 0,29 & 0,27 & 0 \\
\hline Snow heat conductivity $(\lambda, w / m . K)$ & 0,106 & 0,146 & 0,171 & 0,179 & 0,187 & 0,195 & 0,211 & 0,227 & 0,290 \\
\hline Snow volumetric heat conductivity $\left(\mathrm{C}, \mathrm{MJ} /\left(\mathrm{m}^{3} . \mathrm{K}\right)\right.$, & 0,30 & 0,42 & 0,49 & 0,51 & 0,54 & 0,56 & 0,61 & 0,65 & 0,82 \\
\hline
\end{tabular}

Table 4: Computation results for crack formation

\begin{tabular}{|c|c|c|c|c|c|c|}
\hline \multirow[b]{2}{*}{$\begin{array}{l}\text { Dam } \\
\text { type }\end{array}$} & \multirow[b]{2}{*}{$\begin{array}{l}\text { Dam } \\
\text { zone }\end{array}$} & \multirow[b]{2}{*}{$\begin{array}{l}\text { Snow cover } \\
\text { availability }\end{array}$} & \multirow[b]{2}{*}{$\begin{array}{l}\text { Period from Winter to } \\
\text { crack formation, beginning }\end{array}$} & \multicolumn{3}{|c|}{ Cracking parameters (M) } \\
\hline & & & & Crack depth & Crack opening width & Inter-crack distance \\
\hline Thawed & Pre-p ond & No & 38 & 0,78 & 0,030 & 1,7 \\
\hline -"- & -"- & Yes & & Not cracked & & \\
\hline -"- & Lateral & No & 38 & 0,80 & 0,032 & 1,7 \\
\hline -"- & -"- & Yes & & Not cracked & & \\
\hline Frozen & Pre-p ond & No & 28 & 1,1 & 0,043 & 1,1 \\
\hline -"- & $-"-$ & Yes & 113 & 8,4 & 0,043 & 19 \\
\hline -"- & Lateral & No & 28 & 1,2 & 0,037 & 1,1 \\
\hline -"- & ."- & Yes & 112 & 8,3 & 0,037 & 17,6 \\
\hline
\end{tabular}

\section{RESULTS AND DISCUSSION}

Availability of a snow cover on the frozen-type dam significantly (4 times) increased time periods that passed before cracking started. As for a thawed-type dam, snow layer of $0,3 \mathrm{~m}$ high prevented cracks forming both in the dam pre-pond and lateral zones (Table 4).

Cracking parameters depended on the dam type. Crack depth and width were bigger in the frozen dam type. At the same time, the inter-crack distance was bigger in the thawed dam type as compared to the frozen one if there was no snow. In case of a snow cover $(0 ; 3 \mathrm{~m}$ thick), the inter-crack distance and crack depth considerably increased in the frozen type dam. According to the calculations, there was a minor difference between cracking parameters for the pre-pond and lateral zones for each dam type.

The cracking start time dependence vs. the dam type is regular. The snow cover on the dam surface is a heat-insulator and consequently, the temperature of the dam surface increases by $4-5^{\circ} \mathrm{C}$ with all that it implies
Comparison of the obtained results with the field survey data shows that the above method may be used to define cracking parameters in tailing dams with the accuracy sufficient for practical purposes. It should be noted that significant non-uniform vertical and horizontal dam deformations and carry-over of tailing fine fractions by a seepage flow were later revealed in the areas of intensive cracking (between stakes 26 and 30,34 and 40).

\section{CONCLUSION}

In winter, cracks are formed on the surface of a tailing dump dam raised from tailings. Crack depth reaches $1.2-1.5 \mathrm{~m}$ and more, crack width reaches $0.025-0.105 \mathrm{~m}$. The method used allows definition of cracking parameters (crack depth and width, inter-crack distance) with the accuracy sufficient for practical purposes. 


\section{REFERENCES}

Argimbaev, K.R., 2016. Simulation of a geomechanical monitoring algorithm for open-pit mining. Res. J. Appl. Sci., 11: 811-815.

Argimbaev, K.R., D.N. Ligotsky and A.S. Govorov, 2018. Technology of developing a man-made deposit of rare elements at high temperatures. J. Eng. Appl. Sci., 13: 1632-1637.

Balaji, G., S. Vengataasalam and S. Sekar, 2013. Numerical investigation of second order singular system using single-term Haar wavelet series method. Res. J. Applied Sci., 8: 9-13.

Danilov, A.S., U.D. Smirnov and M.A. Pashkevich, 2015. The system of the ecological monitoring of environment which is based on the usage of UAV. Russ. J. Ecol., 46: 14-19.

Gavrishev, S.E., K.V. Burmistrov, S.N. Kornilov and N.G. Tomilina, 2016. Evaluation of transportation flow charts with open-pit hoisting systems in open pit/underground mining. Gornyi Zh., 5: 41-47.
June, L.W. and W.S. Khalaf, 2009. A linear programming approach for the project controlling. Res. J. Applied Sci., 4: 202-212.

Kaerbek, R.A. and H.A. Kholodjakov, 2016. Development of numerical models for rock mass stress-strain behavior forecasting during ore deposit open-pit mining. Res. J. Appl. Sci., 11: 281-286.

Kholodnyakov, G.A. and K.R. Argimbayev, 2014. The choice and substantiation of the technological parameters of tailing formation in an overburden dump body. Scientific Bull. National Mining Univ., 2: $50-57$.

Pashkevich, M.A. and T.A. Petrova, 2015. The investigation of toxic waste burial polygon impact on the atmospheric air using lichenoindication method (Russia). Intl. J. Ecol. Dev., 30: 98-105.

Pikalov, V.A., A.V. Sokolovsky, V.N. Vasilets and K.V. Burmistrov, 2016. Substantiation of efficient parameters for hybrid open pit-underground mining of coal. Gornyi Zhurnal, 1: 67-72.

Sarma, S.K., 1979. Stability analysis of embankments and slopes. J. Geotech. Geoenviron. Eng., 105: 1511-1524. 